\title{
Saprophytic Intracellular Rhizobia in Alfalfa Nodules
}

\author{
Antonius C. J. Timmers, Eric Soupène, Marie-Christine Auriac, Françoise de Billy, Jacques Vasse, \\ Pierre Boistard, and Georges Truchet \\ Laboratoire de Biologie Moléculaire des Relations Plantes-Microorganismes, CNRS-INRA, BP 27, 31326 \\ Castanet-Tolosan Cedex, France. \\ Accepted 20 July 2000.
}

In indeterminate alfalfa nodules, the establishment of the senescent zone IV, in which both symbionts undergo simultaneous degeneration, has been considered, until now, as the end point of the symbiotic interaction. However, we now describe an additional zone, zone $V$, proximal to the senescent zone IV and present in alfalfa nodules more than 6 weeks old. In zone $V$, a new round of bacterial release occurs from remaining infection threads, leading to the reinvasion of plant cells that have completely senesced. These intracellular rhizobia are rod shaped and do not display the ultrastructural differentiation features of bacteroids observed in the more distal zones of the nodule. Interestingly, we have found that oxygen is available in zone $V$ at a concentration compatible with both bacterial development and nitrogen fixation gene expression in newly released rhizobia. However, this expression is not correlated with acetylene reduction. Moreover, the pattern of nifH expression in this zone, as well as new data relating to expression in zone II, strongly suggest that nifH transcription in the nodule is under the control of a negative regulator in addition to oxygen. Our results support the conclusion that zone $V$ is an ecological niche where intracellular rhizobia take advantage of the interaction for their exclusive benefit and live as parallel saprophytic partners. The demonstration of such an advantage for rhizobia in nodules was the missing evidence that Rhizobium-legume interactions are indeed symbiotic and, in particular, suggests that benefits to the two partners are associated with different developmental stages within the nodule.

Additional keywords: nodulation, nodule development, rhizobium, symbiosis.

The symbiotic interaction between prokaryotic rhizobia and leguminous plants results in the formation of novel plant organs known as nodules. Within nodules, the microsymbiont uses photosynthesis-derived energy to convert atmospheric nitrogen into ammonia, a form of reduced nitrogen that is assimilated by the plant.

Root nodulation starts with a molecular dialogue between the two partners (Dénarié et al. 1996; Long 1996) and takes

Corresponding author: G. Truchet; Telephone: +33 5612850 51; Fax: +33 561285061 ; E-mail: truchet@toulouse.inra.fr

Current address of E. Soupène: Department of Plant and Microbial Biology, 111, Koshland Hall, University of California, Berkeley 94720, U.S.A.

A. C. J. Timmers and E. Soupène contributed equally to the paper. place through a series of developmental stages (Brewin 1991; Hirsch 1992; Kijne 1992; Schultze and Kondorosi 1998; Timmers et al. 1998, 1999; Vasse et al. 1990). In temperate legumes such as clover, pea, or alfalfa, cell division is observed in the root pericycle and in the root cortex where the nodule primordium forms (Libbenga and Harkes 1973; Timmers et al. 1999). Simultaneously, root hairs curl and are infected by means of infection threads that convey the rhizobia to the innermost initial primordial cell layer (Timmers et al. 1999; van Brussel et al. 1992). After initial infection, cells in a medial position within the primordium undergo a complete dedifferentiation process, resulting in the formation of the nodule meristem that ensures nodule growth (Timmers et al. 1999).

The persistent activity of the meristem results in the development of elongate indeterminate nodules which, until now, have been subdivided into five central zones that differentiate successively from the tip (distal) to the base (proximal) of the nodule (Vasse et al. 1990): the apical meristematic zone I, which ensures continued nodule growth over many weeks; the prefixing (infection) zone II, in which bacteria are released from growing infection threads; the narrow interzone II-III, representing major developmental changes and characterized by the accumulation of starch in plastids; zone III, which can be subdivided into a distal nitrogen-fixing region and a proximal nonfixing region; and, finally, the senescent zone IV, characterized by the degeneration of both symbionts.

Symbionts undergo simultaneous differentiation as the nodule grows and the term "bacteroid" refers to the symbiotic intracellular form of the microsymbiont (Bergersen 1974). In alfalfa, five ultrastructural types of bacteroid differentiation (types 1 to 5) have been described, each restricted to a welldefined histological region of the nodule (Vasse et al. 1990). Ultrastructurally, most of the bacteroid types appear different from the free-living, rod-shaped rhizobia, with the exception of type 1 , the newly released and actively dividing bacteroids in distal zone II (Paau et al. 1978, 1980; Vasse et al. 1990). Simultaneously to bacteroid differentiation, dramatic changes occur in invaded plant cells, which enlarge, become highly polyploid (Truchet 1980), and are the site of a comprehensive reorganization of the cytoplasm thay can be correlated with microtubular cytoskeleton rearrangements (Timmers et al. 1998). Following nitrogen fixation, rapid degeneration of both symbionts initiates at the proximal end of zone III, resulting in the formation of the senescent zone IV, where plant cells only contain plant organelle- and bacteroid-derived membranes (Kijne 1975; Paau et al. 1978; Truchet and Coulomb 1973; Vance et al. 1980; Vasse et al. 1990). In alfalfa, degeneration 
occurs significantly earlier in inefficient nodules either elicited by Fix ${ }^{-}$Sinorhizobium meliloti mutant strains (Vasse et al. 1990) or resulting from deficiencies in the host plant (Vance and Johnson 1983).
Symbiont degeneration is generally considered to be the end point of the symbiotic interaction. However, we now describe a new zone, zone $\mathrm{V}$, that differentiates at the most proximal end of the nodule after the symbionts have senesced in zone
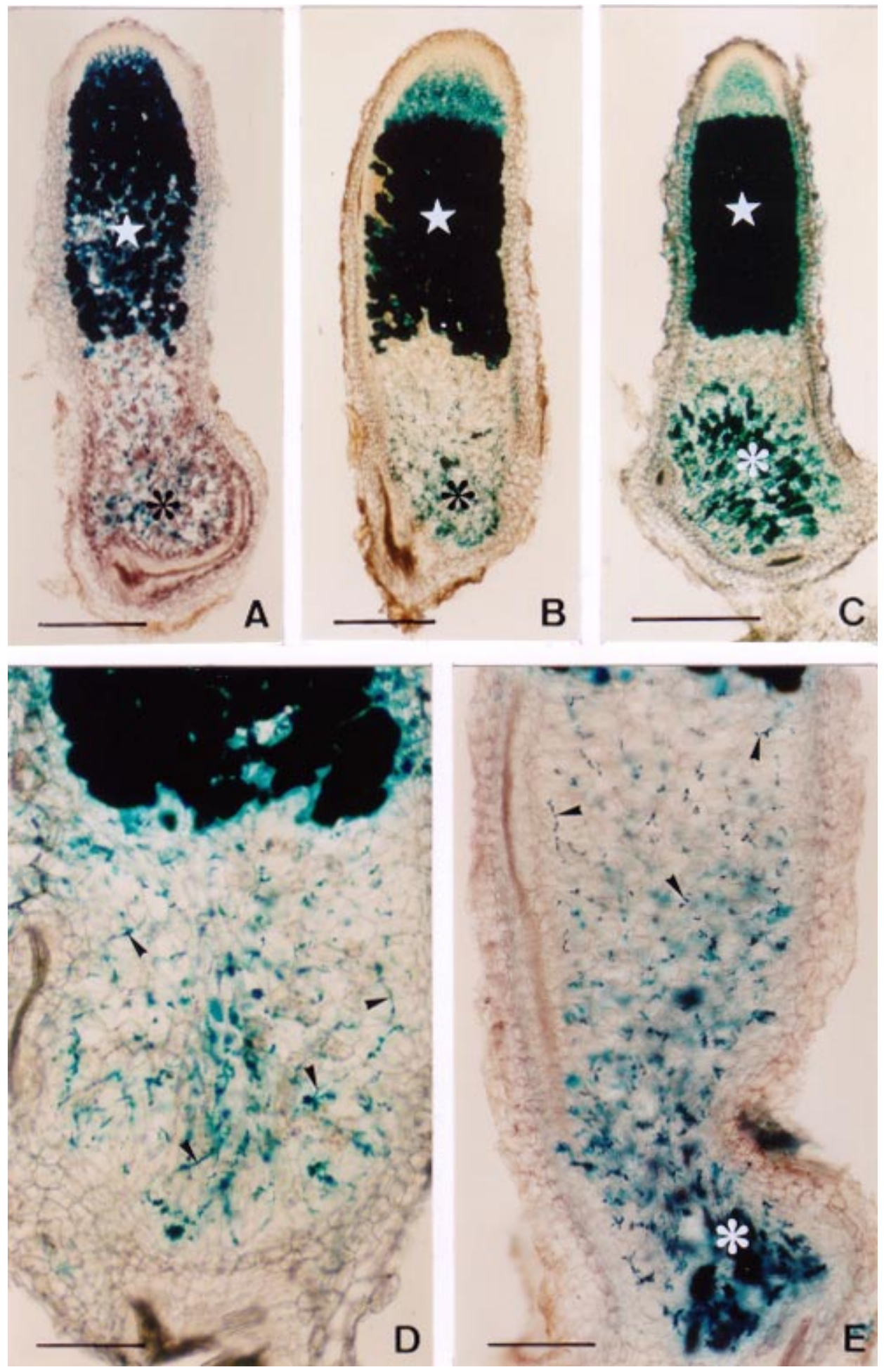

Fig. 1. Differentiation of zone $\mathrm{V}$ in alfalfa nodules. Bright field microscopy of longitudinal sections of nodules elicited by a bacterial strain carrying a hemA::lacZ gene. $\beta$-galactosidase staining. A-C, Different stages of differentiation of zone $\mathrm{V}$ at the proximal region (asterisk) of nodules collected $\mathbf{A}$, 5; B, 7; and C, 9 weeks after inoculation. White stars = zone III. Bars $=200 \mu \mathrm{m}$. D, Infection network (arrowheads) in the proximal postsenescent region of a 6-week-old nodule. E, Intracellular rhizobia in cells of zone V (asterisk) of a 9-week-old nodule. Arrowheads $=$ infection threads. Bars $=50 \mu \mathrm{m}$. 
IV. Zone V results from a new round of plant cell invasion by rhizobia that are not surrounded by a membrane envelope, do not undergo bacteroid differentiation, and possess ultrastructural features of free-living bacteria. Both nif and fix genes are strongly expressed in bacteria in zone $\mathrm{V}$, although no acetylene reduction can be detected. The significance of this new proximal zone $\mathrm{V}$ in terms of the mutualistic interaction will be discussed.

\section{RESULTS}

\section{Identification of a new histological zone, zone $\mathrm{V}$, in alfalfa nodules.}

Histological studies were performed on longitudinal sections of nodules harvested at weekly intervals from week 3 through week 12 following inoculation of alfalfa with the strain S. meliloti GMI6526 (Table 1). This strain carries a constitutively expressed hemA/lacZ fusion that allows the visualization of bacteria throughout nodule development. Examination of a minimum of 10 nodules per time point showed the typical organization of indeterminate nodules with central tissues organized into successive zones: the apical meristematic zone I; the bacteroid-infected zones II, II-III, and III; and the proximal senescent zone IV, comprising cells that appear empty under light microscopic observation (Fig. 1A to C) (Vasse et al. 1990). In addition, from 5 weeks after inoculation onward, $\beta$-galactosidase staining revealed the presence of the microsymbiont in cells located proximally to senescent zone IV, thus defining a new central zone, zone V (Fig. 1C). Detailed observations showed that, in zone $\mathrm{V}, \beta$-galactosidase activity could be correlated with the presence of bacteria, either retained in infection threads (Fig. 1D and E) or intracellular within senescent plant cells (Fig. 1C and E). Zone V was only rarely observed in nodules at 5 weeks postinoculation, but became clearly distinct in older nodules 7 to 12 weeks postinoculation.

\section{Rhizobia are released passively from infection threadsin zone $V$.}

We investigated the origin of rhizobia in zone $\mathrm{V}$ by two approaches. First, we examined whether cell reinvasion in zone $\mathrm{V}$ could be due to the penetration of rhizosphere-located rhizobia from the proximal sides of the nodule adjacent to the senescent region. To test this, we inoculated alfalfa with the wild-type strain S. meliloti 2011 and then reinoculated the same plants, 3 weeks later, with the isogenic strain GMI6526 containing a constitutively expressed hemA/lacZ fusion. Nodules were collected 5 weeks after the second inoculation and stained for $\beta$-galactosidase activity. The fact that enzymatic activity was never observed in any of the nodule tissues, whereas rhizobia were frequently observed in the proximal zone $\mathrm{V}$, indicated that the presence of rhizobia in zone $\mathrm{V}$ could not be due to nodule invasion by rhizospheric rhizobia (data not shown). Second, we used electron microscopy to study cell reinvasion, assuming that this could be the result of a new round of bacterial release from the numerous infection threads observed in zone V (Fig. 1). Despite many observations, there was no indication that rhizobial release in zone $\mathrm{V}$ occurred by an endocytotic process similar to that observed in distal zone II of the nodule (data not shown) (Kijne 1992). However, we repeatedly observed that infection digitations protruding into cells in zone $\mathrm{V}$ underwent dramatic changes. These resulted, first, in a lack of plant-derived membrane (i.e., plasmalemma) at the thread's periphery and, next, in a progressive disorganization of the cell wall. The wall becomes thinner by the progressive loss of its fibrillar constituents (compare Fig. 2A with $2 \mathrm{~B}$ and $\mathrm{C}$ ), which can be clearly seen distributed within the recipient plant cell (Fig. 2D). At the end of this process, the bacteria passively leave the thread's mucilage to invade the cell volume (Fig. 2D). These observations, and the fact that no ultrastructural intermediates appear to exist between the highly differentiated bacteroids (Fig. 2A) (Vasse et al. 1990) and the rod-shaped rhizobia in zone $\mathrm{V}$ (Fig. $2 \mathrm{E}$ and F), make it unlikely that there is a direct link between the two types of intracellular bacteria and led us to the conclusion that late rhizobial release in zone $\mathrm{V}$ occurs passively from infection threads.

Electron microscopy was also used to define the ultrastructural features of both symbionts in zone V. We first confirmed that rhizobia were able to reinvade highly senescent plant cells (Fig. 2E) containing ghost membranes, probably of both plant and bacteroid origin (Fig. 2B and C). Interestingly, intracellular bacteria in zone $\mathrm{V}$ never show any of the ultrastructural differentiation features of bacteroids in the distal zones of the nodule (Vasse et al. 1990) and are not surrounded by a peribacteroid membrane (Fig. 2D). Ultrastructurally, rhizobia in zone $\mathrm{V}$ generally possessed a rod-shaped morphology (Fig. $2 \mathrm{D}$ to $\mathrm{F}$ ), although extended focus image confocal microscopy revealed that they could elongate slightly (Fig. 3B),

Table 1. Sinorhizobium meliloti strains used in this study

\begin{tabular}{|c|c|c|}
\hline Strain & Relevant characteristics & References \\
\hline RCR2011 & SU47, wild type, $\mathrm{Nod}^{+} \mathrm{Fix}^{+}$ & Rosenberg et al. 1981 \\
\hline GMI5600 & lac, pSym20::Tn5, Nod $^{+} \mathrm{Fix}^{+}$ & David et al. 1988 \\
\hline GMI6526 & (pXLGD4), Nod $^{+} \mathrm{Fix}^{+}$ & Ardourel et al. 1994 \\
\hline GMI6473 = GMI5600(pCHK57) & lac, pnifA-lacZ, Nod $^{+} \mathrm{Fix}^{+}$ & Soupène et al. 1995 \\
\hline GMI6334 = GM5600(pRKP9) & lac, pnifH-lacZ, $\mathrm{Nod}^{+} \mathrm{Fix}^{+}$ & This study \\
\hline GMI6324 = GMI5600(pJJ5) & lac, $\mathrm{p}$ fixK-lacZ, $\mathrm{Nod}^{+} \mathrm{Fix}^{+}$ & Soupène et al. 1995 \\
\hline GMI11251 = GMI5600(pML330) & lac, plac-fixJC, pnifH-lacZ, $\mathrm{Nod}^{+} \mathrm{Fix}^{+}$ & This study \\
\hline GMI5801 & (pGMI149nodA::lacZ), Nod $^{+} \mathrm{Fix}^{+}$ & Maillet et al. 1990 \\
\hline GMI6028 & $\left(\mathrm{pRm} 57\right.$ nodC::lacZ), $\mathrm{Nod}^{+} \mathrm{Fix}^{+}$ & Mulligan and Long 1985 \\
\hline GMI395 & fixL::Tn5\#2.66, Nod $^{+} \mathrm{Fix}^{-}$ & David et al. 1988 \\
\hline GMI347 & fixJ::Tn5\#2.3, Nod $^{+} \mathrm{Fix}^{-}$ & Batut et al. 1985 \\
\hline GMI5443 & fixG::Tn5\#2.247, Nod $^{+} \mathrm{Fix}^{-}$ & Kahn et al. 1989 \\
\hline GMI5441 & fixH::Tn5\#2.222, $\mathrm{Nod}^{+} \mathrm{Fix}^{-}$ & Kahn et al. 1989 \\
\hline GMI351 & fixI::Tn5\#2.1, Nod $^{+}$Fix $^{-}$ & Kahn et al. 1989 \\
\hline Rm1021(pHC60) & GFP-S65T, Nod $^{+}$Fix $^{+}$ & Cheng and Walker 1998 \\
\hline
\end{tabular}


thus resembling free-living rhizobia. However, they appeared different from their siblings retained in the infection threads, because they possessed a more homogenous cytoplasm with a clear nucleoid central zone and lacked poly- $\beta$ hydroxybutyrate granules (compare Fig. $2 \mathrm{~B}$ and $\mathrm{C}$ with $2 \mathrm{~F}$ ). These differences are probably due to more favorable nutrient conditions for rhizobia in zone $\mathrm{V}$ compared with bacteria retained in infection threads.

\section{Cell reinvasion is widely observed in $\mathrm{Fix}^{-}$nodules.}

Cell reinvasion occurs after nodule cells have senesced naturally; therefore, we further investigated the correlation between senescence and cell reinvasion by using different $S$. meliloti mutant strains carrying Tn5 insertions in fix genes (Table 1). On alfalfa, Fix ${ }^{-}$S. meliloti mutants induce nonnitrogen-fixing nodules, which senesce much earlier and more rapidly than wild-type nodules ( 2 to 3 weeks after in-
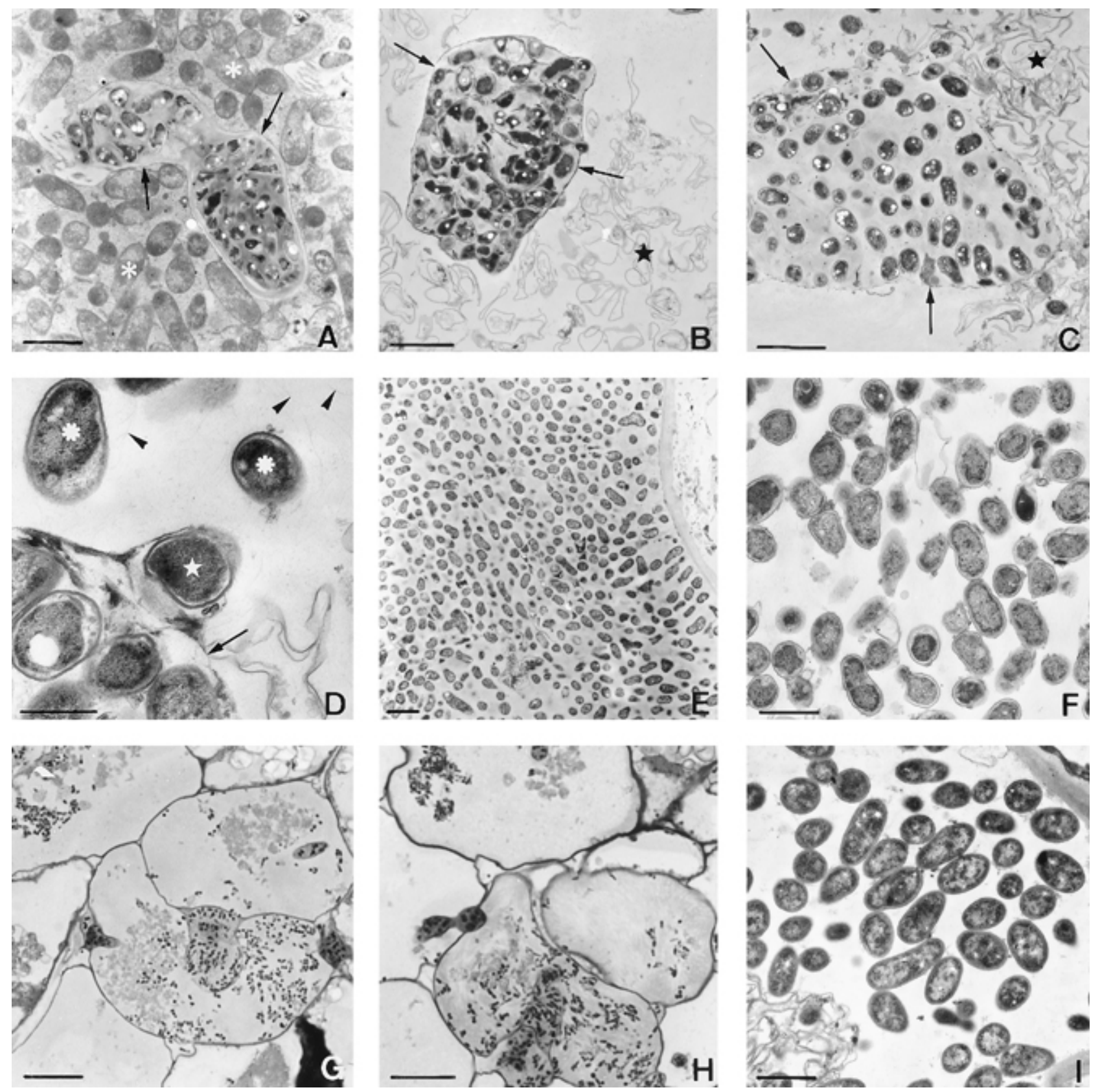

Fig. 2. A-F, Ultrastructural studies of zone $V$ in nitrogen-fixing nodules using transmission electron microscopy. A-C, Ultrastructural changes of infection thread digitations. Progressive disorganization of the cell wall (arrows) of infection thread digitations from A, a cell in zone III filled with nitrogenfixing bacteroids (asterisks) to $\mathbf{B}$ and $\mathbf{C}$, cells in zone V containing ghost membranes (stars). Note that no plasmalemma-derived membrane surrounds the infection thread wall in zone V. Bars $=2 \mu \mathrm{m}$. D, Rhizobia late release (star) taking place in zone $\mathrm{V}$ where infection thread cell wall is disorganized (arrow). Note the lack of plant-derived membrane around released rhizobia (asterisks). Arrowheads point to fibrillar material in the lumen of the cell. $\mathbf{E}$ and F, Nodule cells filled with rod-shaped rhizobia. Bars: $\mathbf{D}$ and $\mathbf{F}=1 \mu \mathrm{m}$; and $\mathbf{E}=2 \mu \mathrm{m}$. G-I, Rod-shaped intracellular rhizobia in Fix ${ }^{-}$nodules. $\mathbf{G}$ and $\mathbf{H}$, Light micrographs showing the presence of rhizobia in senescing cells of nodules elicited by Sinorhizobium meliloti strains mutated in $\mathbf{G}$, fixL and $\mathbf{H}$, fixJ. I, Electron micrograph of rhizobia in a nodule elicited by a fixL mutant. Bars: $\mathbf{G}$ and $\mathbf{H}=25 \mu \mathrm{m} ; \mathbf{I}=1 \mu \mathrm{m}$. 
oculation versus 4 to 5 weeks) (Vasse et al. 1990). Histological and ultrastructural studies showed that proximal cells of Fix ${ }^{-}$nodules elicited by rhizobial mutants carrying a mutation in fix genes (fixL, fixJ, fixG, fixH, or fixI) (Table 1) were indeed reinvaded with rod-shaped vegetative bacteria displaying the morphology and ultrastructural features similar to those of intracellular rhizobia described in zone $\mathrm{V}$ of wild-type nodules (Fig. 2G to I; compare Fig. 2F with
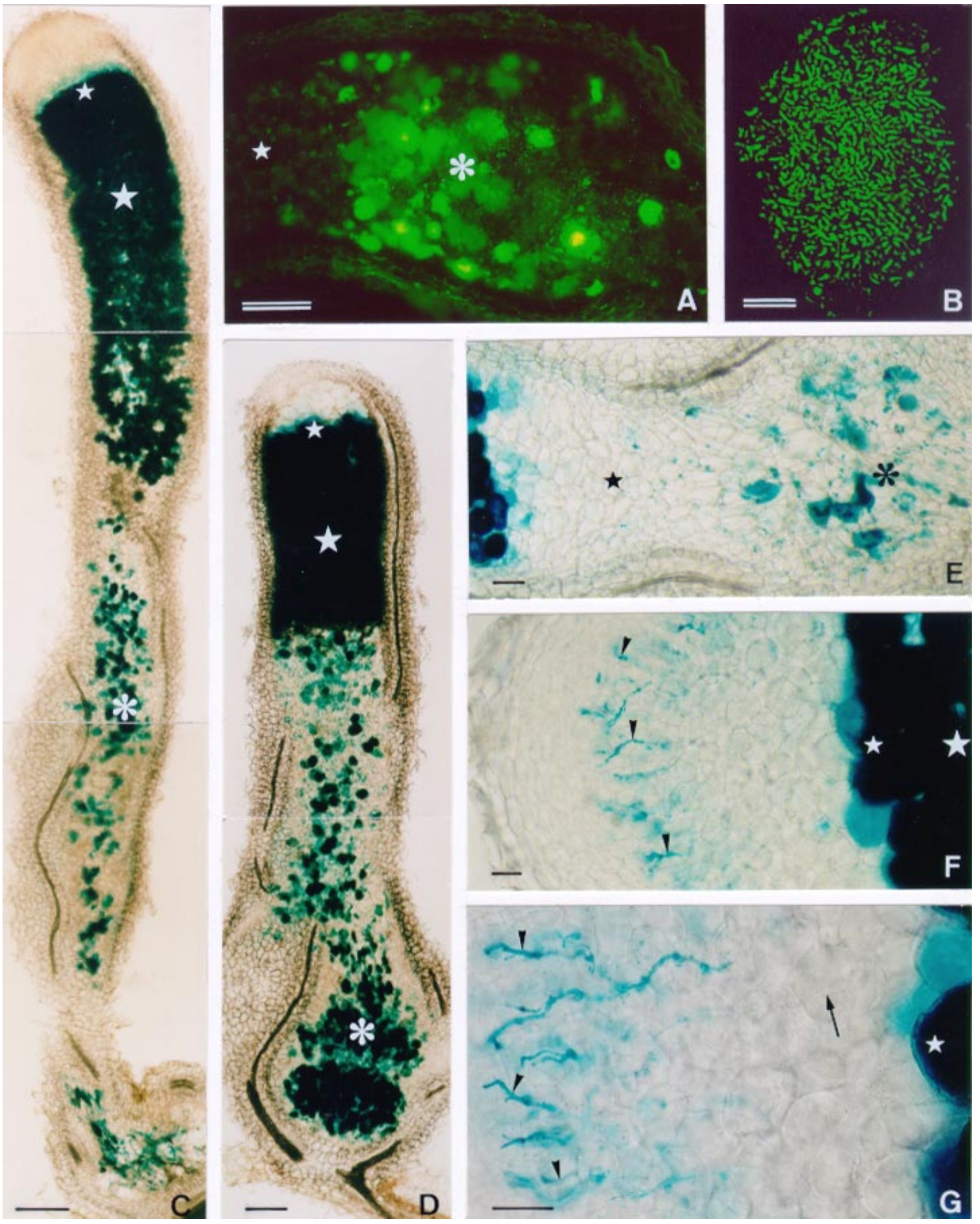

Fig. 3. A and B, GFP fluorescence in 9-week-old wild-type nodules. A, Fluorescence microscopy in zone V (asterisk). Star $=$ senescent zone IV. B, Laser confocal microscopy of a cell filled with rhizobia in zone V. Bars: $\mathbf{A}=50 \mu \mathrm{m}$; and $\mathbf{B}=10 \mu \mathrm{m}$. C-G, $\beta$-galactosidase activity in 10 -week-old nodules elicited by Sinorhizobium meliloti strains containing a fusion of nif and fix gene promotors to the lac $Z$ reporter gene. $\mathbf{C}$, nif $A$ and $\mathbf{D}$, fixK expression in zone V (asterisks). E, nif $H$ expression in the proximal zone V (asterisk), but not in the senescent zone IV (star). F and G, Nodules in microoxic conditions; nifH expression in bacteria retained in infection threads located exclusively at the most distal end of zone II (arrowheads) but not G, in infection threads in the proximal end (arrows). Small stars = interzone II-III; large stars = zone III. Bars: C and D $=100 \mu \mathrm{m} ; \mathbf{E}-\mathbf{G}=200 \mu \mathrm{m}$. 
2I). However, in such nodules, cell reinvasion observed in cells adjacent to those where senescence occurred was always restricted to a relatively few number of nodule cells (Fig. 2G and $\mathrm{H}$ ) and did not result in the differentiation of an extended zone $\mathrm{V}$ as in wild-type nodules (Fig. 1C and E). These data show that senescence and passive bacterial release appear to be correlated and that the differentiation of intracellular rhizobia in zone $\mathrm{V}$ is not dependent upon nodule efficiency.

\section{Oxygen is available in zone $\mathrm{V}$.}

The fact that rhizobia are strictly aerobic and that rhizobia develop actively in zone $\mathrm{V}$ prompted us to address the question of oxygen supply in zone $\mathrm{V}$ by using a $S$. meliloti strain carrying a green fluorescent protein (GFP) fusion (Table 1). The formation of the GFP chromophore is oxygen dependent (Tsien 1998); therefore, the emission of fluorescence in a particular region of the nodule would show that oxygen is available in this region. By conventional or confocal microscopy of longitudinal sections of 9-week-old alfalfa nodules, we observed a strong GFP fluorescence in rhizobia in zone $\mathrm{V}$, both in bacteria retained in infection threads and intracellularly (Fig. $3 \mathrm{~A}$ and $\mathrm{B}$ ). These results indicate that, in zone $\mathrm{V}$, oxygen is present in both apoplastic and symplastic cell compartments at a concentration sufficient for chromophore functioning and rhizobial survival.

\section{Expression of nif and fix genes in intracellular rhizobia in zone $\mathrm{V}$ is not correlated with nitrogenase activity.}

The symbiotic expression of either nod genes or nif and fix genes in rhizobia is highly regulated (Dénarié et al. 1996; Kaminski et al. 1998). To further assess the nature of the cell environment in zone $\mathrm{V}$, we studied whether nod, nif, and fix genes are expressed in rhizobia in zone V. For this purpose, 9week-old nodules were harvested from plants inoculated with various $S$. meliloti wild-type strains, each strain containing a plasmid carrying a fusion between the nod/niflfix gene and the lacZ reporter gene (Table 1). Histological observation of longitudinal sections showed that nodA and nodC are not expressed in rhizobia in zone $\mathrm{V}$ (data not shown). However, expression of nifA, nifH, and fixK was observed in bacteroids starting at the interzone II-III, as shown previously by Soupène et al. (1995) (Fig. 3C and D), as well as in vegetative bacteria either enclosed in the remaining infection threads present in central tissues or released in the cells of zone $\mathrm{V}$ (Fig. 3C-E). This indicates that conditions required for the expression of the nif and fix rhizobial genes are present in both apoplastic and symplastic cellular compartments of zone V. However, as compared with nifA and fixK, which are highly expressed throughout the entire zone V (Fig. 3C and D), nifH is not expressed in bacteria retained in infection threads in senescent zone IV. Expression of this nifH gene in zone $\mathrm{V}$ is limited to a certain proportion of nodules and, in these cases, it is always limited to the most proximal region (Fig. 3E).

This result is reminiscent of the observation that a reduction of oxygen concentration leads to the expression of nifA and fixK, but not nifH, in zone II (Soupène et al. 1995). Therefore, nifH expression could be subject to additional regulation compared with nifA and fixK. In order to investigate this, we monitored expression in nodules elicited by a strain that constitutively expresses NifA, independently of the oxygen concentration, and placed in a microoxic environment to permit the activity of the oxygen-sensitive NifA protein (Kaminski et al. 1998). Three-week-old nodules elicited by the strain $S$. meliloti GMI11251 carrying the plasmid pML330 (Table 1) were placed in microoxic conditions using the same methodology as that described in Soupène et al. (1995). This plasmid carries a nifH/lacZ fusion and expresses an oxygenindependent active form of FixJ, FixJC, which allows a high level of nifA expression under the lac promoter, even in the presence of oxygen (Kahn and Ditta 1991). Interestingly, we observed (i) normal nifH gene expression starting at interzone II-III and (ii) in the majority of nodules, ectopic nifH expression in bacteria retained in infection threads and probably also in bacteroids located exclusively in a submeristematic position (i.e., the most distal part of zone II). Gene expression was not observed in bacteria located in infection threads or in bacteroids lying in proximal zone II (Fig. 3F and G). This observation strongly supports the hypothesis that a second signal acts together with oxygen to pattern symbiotic nifH expression.

Our last objective was to investigate whether rhizobia in zone $\mathrm{V}$ possess nitrogen-fixing activity. For this purpose, eight 11-week-old nitrogen-fixing nodules elicited by $S$. meliloti GMI6526 carrying a hemA/lacZ fusion were sectioned transversally, after which each nodule segment was individually assayed for nitrogenase activity. We found that only the distal segments, encompassing bacteroidal tissues, and particularly zone III, were able to reduce acetylene (mean rate of $276 \pm 64 \mathrm{~nm}$ after $60 \mathrm{~min}$ of incubation time). In contrast, none of the proximal segments were active in reducing acetylene, although staining for $\beta$-galactosidase activity after the acetylene reduction assay confirmed the presence of zone $\mathrm{V}$ containing intracellular rhizobia (data not shown). This indicates that intracellular rhizobia in zone $\mathrm{V}$ do not fix nitrogen within the limit of detection.

\section{DISCUSSION}

\section{Early and late bacterial release in alfalfa nodules.}

The presence of vegetative bacteria either in intercellular spaces (Thornton 1930) or in highly disorganized cells has already been reported in wild-type or inefficient nodules of different legumes such as alfalfa (Paau et al. 1980; Thornton 1930; Vance et al. 1980), pea (Kijne 1975), clover (Mosse 1964; Thornton 1930), and Lotus corniculatus (Vance et al. 1982). Our results confirm the presence of vegetative bacteria, both in the intercellular spaces and in the lumen of central cells of the most proximal part of alfalfa indeterminate nodules (i.e., after the bacteroidal tissue has senesced in zone IV). Based on microscopic studies, it is clear that this late rhizobial release proceeds through a mechanism that differs fundamentally from early release. Early release is a highly controlled process restricted to the distal part of the submeristematic prefixing (infection) zone II (Vasse et al. 1990), involving an endocytotic mechanism that solicits the plant plasmalemma and the endomembrane synthesis machinery to form a symbiosome, the structural entity comprising an intracellular bacterium and its plasmalemma-derived peribacteroid membrane (Roth and Stacey 1989). In contrast, late release in zone V occurs, as previously suggested in pea (Kijne 1975), via a passive mechanism following cell degeneration and cell wall disorganization of infection threads lying in the intercellular spaces of metabolically inert cells having reached the end 
point of the senescence process. Therefore, late release should be considered the result of a noncontrolled reinvasion process rather than an infection process sensu stricto.

Late release of rhizobia leads to the differentiation of a postsenescence nodule zone that we propose to call the saprophytic zone $\mathrm{V}$, in line with the histological nomenclature of indeterminate nodules (Vasse et al. 1990) and the fact that bacteria in this zone do not reduce nitrogen and do not appear to induce disease symptoms on the host plant. Zone V comprises senescent cells that are either microscopically empty or filled with intracellular bacteria. Until now, the term "bacteroid" referred to the symbiotic intracellular bacteria without regard to size, shape, and location (Bergersen 1974). In alfalfa, bacteroids undergo a series of morphological and ultrastructural changes that are correlated with nodule functioning from distal zone II through to senescent zone IV (Timmers et al. 1999; Vasse et al. 1990). By contrast, although intracellular, late-released rhizobia of zone $\mathrm{V}$ appear to be fundamentally different from bacteroids in several ways, including their mode of release, histological location, morphology, ultrastructure, function, and behavior. By analogy with the term "bacteroid" which identifies the intracellular bacteria in the distal central zones, we propose the term "rhizoboid" for intracellular rhizobia in the proximal zone $\mathrm{V}$.

\section{Questions regarding symbiotic nitrogen fixation gene expression.}

Symbiotic expression of nitrogen fixation genes, such as fixK, nifA, and nifH in S. meliloti, is under the control of the two-component regulatory system, fix $L J$, responding to microoxic conditions (David et al. 1988; Gilles-Gonzalez et al. 1991) both in liquid cultures and in symbiotic conditions (Kaminski et al. 1998; Soupène et al. 1995). In this paper, (i) we confirm our previous results, showing that nitrogen fixation genes are not expressed in zone II but are switched on at interzone II-III (Soupène et al. 1995) and (ii) we show that nifA and fixK, two genes that are expressed in free-living conditions (Batut et al. 1989) and in zone II of nodules in microoxic conditions (Soupène et al. 1995) are also expressed in bacteria either retained in infection threads or intracellular in all nodule zones between interzone II-III and zone V. The same overall pattern of expression is also found for $n i f H$, indicating that bacteroid differentiation is not a prerequisite for the expression of nifA, nifH, and fixK genes in nodules. However, despite these similarities, nifH expression is different from that of nifA and fixK for the following three reasons. First, the gene nifH is not expressed in liquid culture of $S$. meliloti 2011 grown in microoxic conditions (E. Soupène, unpublished data), whereas it is expressed in $S$. meliloti 102F34, a strain in which nifA is expressed at a higher level (Kahn and Ditta 1991; E. Soupène, unpublished data). Second, in a strain overproducing NifA, ectopic expression of nifH in nodules in microoxic conditions is restricted to distal zone II (this study). It should be noted that, in a previous study (Soupène et al. 1995) using a wild-type strain, we did not observe such ectopic nifH expression in distal zone II. It is likely that the ectopic expression of nifH described in this study is due to the high level of NifA resulting from the plac-driven nifA expression. Finally, gene nifH expression in zone $\mathrm{V}$ is restricted to bacteria retained in infection threads and to intra- cellular rhizobia located at the most proximal end of the zone (this study). This contrasts with nifA and fixK, which are strongly expressed in the entire zone. Thus, there is a striking symmetry in the pattern of nifH expression in the nodule. Starting from zone III, where nifH is strongly expressed, there is a succession of zones toward both nodule extremities, where nifH expression is not detected (proximal zone II; zone IV and distal zone V), followed by zones where nifH expression is again visible (distal zone II and proximal zone V). According to these observations, one could speculate that symbiotic nifH transcription is not only under the control of oxygen, but also may depend on an additional negative regulatory control. NifA, which regulates nifH symbiotic expression (David et al. 1988), is a plausible target for this negative control, because such a control is not observed when the expression of nifH is activated by a mutated form of $n t r C$ (Labes et al. 1993). Complementary experiments are required to substantiate the hypothesis of the additional control of nifH expression in nodules, and an alternative regulation pathway for symbiotic expression of nifH, independent of the oxygenlabile NifA protein, cannot be ruled out at the moment.

\section{The significance of zone $\mathbf{V}$.}

Rhizobium-legume interactions are widely considered to be symbiotic and the nodule to be an environmental niche for rhizobia. The existence of zone $\mathrm{V}$ in indeterminate alfalfa nodules obliges us to reassess these questions and, in particular, to address the role of the intracellular rhizobia in zone $\mathrm{V}$ in the context of the Rhizobium-legume interaction. Our data clearly show that, in zone $\mathrm{V}$, intracellular bacteria do not differentiate into bacteroids, do not display nitrogenase activity (although nitrogen fixation genes are expressed), and are not subject to host cell autolytic processes which limit bacteroid viability in the proximal zones III and IV. On the other hand, bacteria benefit from conditions that allow intracellular growth as vegetative rhizobia with the normal rod-shaped morphology of bacteria. Taken together, this strongly suggests that intracellular rhizobia behave as saprophytic rather than symbiotic bacteria in zone V. Such saprophytic behavior of intracellular bacteria has already been evocated in studies dealing with senescence of nitrogen-fixing nodules (Kijne 1975; Thornton 1930; Vance et al. 1982).

If one considers the Rhizobium-legume interaction in its totality, it is obvious that both partners benefit from the interaction: on the one hand, plant growth is dramatically stimulated through atmospheric nitrogen fixation by bacteroids and, on the other hand, the rhizobial population increases significantly in the plant's rhizosphere (Philips et al. 1990). This satisfies the definition of a symbiotic relationship. By contrast, it is interesting to consider the sequential developmental steps in the nodule, none of which individually corresponds to a symbiotic association: bacteria, which multiply at the growing tips of the infection network, are inefficient (Gage et al. 1996); in zone II, bacteroids proliferate in host cells but are not active in nitrogen fixation (Vasse et al. 1990); in zone III, bacteroids are active in nitrogen fixation but no longer multiply (Vasse et al. 1990); and in zone IV, host cell autolysis leads to the senescence of all bacteroids, as deduced from electron microscopy studies (Kijne 1975; Mosse 1964; Paau et al. 1980; Truchet and Coulomb 1973; Vance et al. 1980, 1982). The differentiation of zone V, where intracellular rhi- 
zobia do not display nitrogenase activity (this study), also does not satisfy, on its own, the condition of reciprocal and simultaneous benefit. Nevertheless, we believe that zone V represents an important feature of the symbiotic Rhizobiumlegume interaction. Until now, as underlined by Brewin (1998), it remains to determine the selective advantage for Rhizobium spp. of undergoing a differentiation process that leads, first, to a block in bacterial proliferation and then to a total breakdown of the bacteroid. In our opinion, zone V represents an ecological niche where rhizobia take advantage of the interaction and escape from plant control. Finally, the fact that rod-shaped intracellular rhizobia differentiate in nonnitrogen-fixing nodules also shows that the microsymbiont can benefit selfishly from the association. Thus, the nitrogenfixing nodule is an organ where reciprocal benefits for both partners occur in different regions of the nodule.

During the last decade, an interesting theory has been proposed based on the altruistic behavior of nitrogen-fixing bacteroids that sacrifice their own reproduction to indirectly benefit undifferentiated siblings present in nearby soil or retained in infection threads inside nodules (Jimenez and Casadesus 1989; Olivieri and Frank 1994). Moreover, it is widely accepted that "symbiotic" rhizobia from decomposing nodules reenter the soil as free bacteria (Thornton 1930), although it remains confusing which rhizobial forms have the capacity to readapt to free-living conditions. It seems likely that bacteria that do not undergo the extensive ultrastructural differentiation pathway toward bacteroids (i.e., those retained in infection threads) (Thornton 1930) or viable bacteroids in the most recently infected plant cells (Quispel 1988), probably corresponding to the dividing type 1 rod-shaped bacteroids in distal prefixing zone II (Vasse et al. 1990), both have the capacity to reintegrate the life cycle of Rhizobium spp. in the soil after plant tissue disintegration. We suggest that one function of "altruistic" nitrogen-fixing bacteroids is to sustain nodule lifetime sufficiently to allow the formation of a zone $\mathrm{V}$ whose size increases as a function of nodule age. As a result, intracellular bacteria in zone V, a viable form of "symbiotic" rhizobia, will make a more significant contribution to the increase in bacterial population in the vicinity of a nodulated legume after nodule breakdown.

\section{MATERIALS AND METHODS}

\section{Bacterial strains.}

The bacterial strains used in this study (Table 1) were grown on yeast extract/tryptone (YT) medium supplemented with 6 $\mathrm{mM}$ calcium chloride and appropriate selective antibiotics. Plasmid pML330 present in strain GMI11251 is a cointegrant between pMB210 (pnifH-lacZ) (Better et al. 1985) and pDK330 (plac-fixJC) (Kahn and Ditta 1991). Both vectors were linearized with HindIII and ligated together. In the recombinant pML330, the promoters plac and pnifH are divergent. Plasmids were introduced into $S$. meliloti by triparental conjugation (David et al. 1988).

\section{Nodulation assays.}

Seeds of Medicago sativa cv. Europe (Florimont Desprez, F59242 Cappelle en Pévèle, France) were surface-sterilized, germinated, and grown in test tubes on nitrogen-free agar slants as described by Ardourel et al. (1994). Plants were flood inocu- lated with exponentially growing bacteria resuspended in water (approximately $10^{6}$ bacteria per $\mathrm{ml}, 100 \mu \mathrm{l}$ per plant). A microoxic environment was established as described in Soupène et al. (1995) with an incubation time in soft agar of $16 \mathrm{~h}$.

\section{Microscopic methods.}

Nodules were harvested at weekly intervals, between 3 and 12 weeks following inoculation, and fixed with a solution of $2.5 \%$ glutaraldehyde in $0.2 \mathrm{M}$ sodium cacodylate $(\mathrm{pH} 7.2)$. The histological organization of nodules was observed either on 80$\mu \mathrm{m}$ longitudinal slices of fixed nonembedded material (Microcut H1200; Bio-Rad Laboratories, Watford, U.K.) (Truchet et al. 1989) or on semithin sections (1 to $2 \mu \mathrm{m})$ of Epon-embedded nodules, stained by the basic fuchsinmethylene blue method (Huber et al. 1968). Observations were performed using either bright field or dark field microscopy with an Olympus Vanox light microscope (Olympus, Tokyo). Ultrastructural differentiation was studied on ultrathin sections of nodules stained with uranyl acetate and lead citrate (Reynolds 1963) and observed with a Hitachi EM 600 electron microscope (Hitachi, Tokyo). $\beta$-galactosidase activity was monitored by light microscopy on $100-\mu \mathrm{m}$ nodule slices stained according to Boivin et al. (1990) and cleared with sodium hypochlorite before observation (Truchet et al. 1989). Fluorescence microscopy (Axiophot 2; Zeiss, Jena, Germany) and confocal laser scanning microscopy (LSM 410 Invert; Zeiss) were performed according to Timmers et al. (1998) on 100- $\mu \mathrm{m}$ longitudinal sections of nodules either untreated and mounted in water or fixed with $4 \%$ formaldehyde in phosphate-buffered saline $(\mathrm{pH} \mathrm{7.4,1} \mathrm{h),} \mathrm{treated}$ with Evans blue (E-2129; Sigma-Aldrich, St. Louis, U.S.A.) to quench autofluorescence, and then mounted in mowiol 4-88 (Calbiochem 475904; Calbiochem, La Jolla, CA, U.S.A.).

\section{Nitrogenase activity.}

Nitrogenase activity was assayed by the acetylene reduction technique (Turner and Gibson 1980). Eleven-week-old nodules elicited by $S$. meliloti GMI6526, a strain carrying a constitutively expressed $l a c Z$ fusion, were transversally cut to generate two nodule halves, the distal region, with the bacteroidcontaining tissues, and the proximal, deflated part. Each half was assayed for nitrogenase activity immediately after dissection as described in Vasse et al. (1990). A sample was scored as $\mathrm{Fix}^{+}$if acetylene-dependent ethylene production could be detected within the 30-min incubation time. After the acetylene reduction assay, the presence of living rhizobia in complementary nodule halves was monitored by $\beta$-galactosidase activity (described above).

\section{ACKNOWLEDGMENTS}

We thank J. Batut, D. Barker, and P. Gamas for helpful comments and valuable criticism of the manuscript; H. Bergès, C. Cosseau, A.-M. Garnerone, and F. Maillet for helpful technical assistance; J. Kijne and C. Vance for providing us with ancestral reprints; and D. Barker for English reviewing. A. C. J. Timmers was supported by a TMR fellowship and this work was funded by a grant from the European Community TMR Programme (FMRW-CT96-0039).

\section{LITERATURE CITED}

Ardourel, M., Demont, N., Debellé, F., Maillet, F., De Billy, F., Promé, J.-C., Dénarié, J., and Truchet, G. 1994. Rhizobium meliloti 
lipooligosaccharide nodulation factors: Different structural requirements for bacterial entry into target root hair cells and induction of plant symbiotic developmental responses. Plant Cell 6:1357-1374.

Batut, J., Daveran-Mingot, M.-L., David, M., Jacobs, J., Garnerone, A.-M., and Kahn, D. 1989. fixK, a gene homologous with $f n r$ and crp from Escherichia coli, regulates nitrogen fixation genes both positively and negatively in Rhizobium meliloti. EMBO J. 8:12791286.

Batut, J., Terzaghi, B., Ghérardi, M., Huguet, M., Terzaghi, E., Garnerone, A.-M., Boistard, P., and Huguet, T. 1985. Localization of a symbiotic fix region on Rhizobium meliloti pSym megaplasmid more than 200 kilobases from the nod-nif region. Mol. Gen. Genet. 199:232239.

Bergersen, F. J. 1974. Formation and function of bacteroids. Pages 476498 in: The Biology of Nitrogen Fixation. A. Quispel, ed. NorthHolland Publishing Company, Amsterdam.

Better, M., Ditta, G., and Helinski, D. R. 1985. Deletion analysis of Rhizobium meliloti symbiotic promoters. EMBO J. 4:2419-2424.

Boivin, C., Camut, S., Malpica, C. A., Truchet, G., and Rosenberg, C. 1990. Rhizobium meliloti genes encoding catabolism of trigonelline are induced under symbiotic conditions. Plant Cell 2:1157-1170.

Brewin, N. J. 1991. Development of the legume root nodule. Annu. Rev. Cell Biol. 7:191-226.

Brewin, N. J. 1998. Tissue and cell invasion by Rhizobium: The structure and development of infection threads and symbiosomes. Pages 417-429 in: Rhizobiaceae, Molecular Biology of Model PlantAssociated Bacteria. H. P. Spaink, A. Kondorosi, and P. J. J. Hooykaas, eds. Kluwer Academic Press, Dordrecht, The Netherlands.

Cheng, H.-P., and Walker, G. C. 1998. Succinoglycan is required for initiation and elongation of infection threads during nodulation of alfalfa by Rhizobium meliloti. J. Bacteriol. 180:5183-5191.

David, M., Daveran, M.-L., Batut, J., Dedieu, A., Domergue, O., Ghai, J., Hertig, C., Boistard, P., and Kahn, D. 1988. Cascade regulation of nif gene expression in Rhizobium meliloti. Cell 54:671-683.

Dénarié, J., Debellé, F., and Promé, J.-C. 1996. Rhizobium lipochitooligosaccharide nodulation factors: Signaling molecules mediating recognition and morphogenesis. Annu. Rev. Biochem. 65:503535.

Gage, D. J., Bobo, T., and Long, S. R. 1996. Use of green fluorescent protein to visualize the early events of symbiosis between Rhizobium meliloti and alfalfa (Medicago sativa). J. Bacteriol. 178:71597166.

Gilles-Gonzalez, M., Ditta, G. S., and Helinski, D. R. 1991. A haemoprotein with kinase activity encoded by the oxygen sensor of Rhizobium meliloti. Nature 150:170-172.

Hirsch, A. M. 1992. Developmental biology of legume nodulation. New Phytol. 122:211-237.

Huber, J. D., Parker, F., and Odland, G. F. 1968. A basic fuchsin and alkalinized methylene blue rapid stain for epoxy embedded tissue. Stain Technol. 43:83-87.

Jimenez, J., and Casadesus, J. 1989. An altruistic model of the Rhizobium-legume association. J. Hered. 80:335-337.

Kahn, D., David, M., Dommergue, O., Daveran, M.-H., Ghai, G., Hirsch, P., and Batut, J. 1989. Rhizobium meliloti fixGHI sequence predicts involvement of a specific cation pump in symbiotic nitrogen fixation. J. Bacteriol. 171:929-939.

Kahn, D., and Ditta, G. 1991. Modular structure of FixJ: Homology of the transcriptional activator domain with the -35 binding domain of the sigma factors. Mol. Microbiol. 5:987-997.

Kaminski, P. A., Batut, J., and Boistard, P. 1998. A survey of symbiotic nitrogen fixation by rhizobia. Pages 431-460 in: Rhizobiaceae, Molecular Biology of Model Plant-Associated Bacteria. H. P. Spaink, A. Kondorosi, and P. J. J. Hooykaas, eds. Kluwer Academic Press, Dordrecht, The Netherlands.

Kijne, J. W. 1975. The fine structure of pea root nodules. 2. Senescence and disintegration of the bacteroid tissue. Physiol. Plant Pathol. 7:17-21.

Kijne, J. W. 1992. The rhizobium infection process. Pages 349-398 in: Biological Nitrogen Fixation. G. Stacey, R. H. Burris, and H. J Evans, eds. Chapmann and Hall, New York.

Labes, M., Rastogi, V., Watson, R., and Finan, T. M. 1993. Symbiotic nitrogen fixation by a nifA deletion mutant of Rhizobium meliloti: The role of an unusual $n t r C$ allele. J. Bacteriol. 175:2662-2673.

Libbenga, K. R., and Harkes, P. A. A. 1973. Initial proliferation of cortical cells in the formation of root nodules in Pisum sativum L. Planta 114:17-28.

Long, S. R. 1996. Rhizobium symbiosis: Nod factors in perspective. Plant Cell 8:1885-1898.

Maillet, F., Debellé, F., and Dénarié, J. 1990. Role of the nod and syrM genes in the activation of the regulatory gene nodD3, and of the common and host-specific nod genes of Rhizobium meliloti. Mol. Microbiol. 4:1975-1984.

Mosse, B. 1964. Electron-microscope studies of nodule development in some clover species. J. Gen. Microbiol. 36:49-66.

Mulligan, J. T., and Long, S. R. 1985. Induction of Rhizobium meliloti nodC expression by plant exudate requires nodD. Proc. Natl. Acad. Sci. USA 82:6609-6613.

Olivieri, I., and Frank, S. A. 1994. The evolution of nodulation in Rhizobium: Altruism in the rhizosphere. J. Hered. 85:46-47.

Paau, A. S., Bloch, C. B., and Brill, W. J. 1980. Developmental fate of Rhizobium meliloti bacteroids in alfalfa nodules. J. Bacteriol. 143:1480-1490.

Paau, A. S., Cowles, J. R., and Raveed, D. 1978. Development of bacteroids in alfalfa (Medicago sativa) nodules. Plant Physiol. 62: 526-530.

Philips, D. A., Harwig, U. A., Maxwell, C. A., Joseph, C. M., Wery, J., Hungria, M., and Tsai, S. M. 1990. Host legume control of nodulation by flavonoids. Pages 331-338 in: Nitrogen Fixation: Achievements and Objectives. P. M. Gresshoff, L. E. Roth, G. Stacey, and W. E. Newton, eds. Chapmann and Hall, New York.

Quispel, A. 1988. Bacteria-plant interactions in symbiotic nitrogen fixation. Physiol. Plant. 74:783-790.

Reynolds, E. S. 1963. The use of lead citrate at high $\mathrm{pH}$ as an electron opaque stain in electron microscopy. J. Cell Biol. 17:208-213.

Rosenberg, C., Boistard, P., Dénarié, J., and Casse-Delbart, F. 1981. Genes controlling early and late functions in symbiosis are located on a megaplasmid in Rhizobium meliloti. Mol. Gen. Genet. 184: 326-333.

Roth, L. E., and Stacey, G. 1989. Bacterium release into host cells of nitrogen-fixing soybean nodules: The symbiosome membrane comes from three sources. Eur. J. Cell Biol. 49:13-23.

Schultze, M., and Kondorosi, A. 1998. Regulation of symbiotic root nodule development. Annu. Rev. Genet. 32:33-57.

Soupène, E., Foussard, M., Boistard, P., Truchet, G., and Batut, J. 1995. Oxygen as a key developmental regulator of Rhizobium meliloti N2fixation gene expression within the alfalfa root nodule. Proc. Natl. Acad. Sci. USA 92:3759-3763.

Thornton, H. G. 1930. The influence of the host plant in inducing parasitism in lucerne and clover nodules. Proc. Roy. Soc. London Ser. B 106:110-122.

Timmers, A. C. J., Auriac, M.-C., de Billy, F., and Truchet, G. 1998. Nod factor internalization and microtubular cytoskeleton changes occur concomitantly during nodule differentiation in alfalfa. Development 125:339-349.

Timmers, A. C. J., Auriac, M.-C., and Truchet, G. 1999. Refined analysis of early symbiotic steps of the Rhizobium-Medicago interaction in relationship with microtubular cytoskeleton rearrangements. Development 126:3617-3628.

Truchet, G. 1980. Sur l'état diploïde des cellules du méristème des nodules radiculaires des légumineuses. Ann. Sci. Nat. Bot. Biol. Vég. 19:3-38.

Truchet, G., Camut, S., de Billy, F., Odorico, R., and Vasse, J. 1989 The Rhizobium-legume symbiosis: Two methods to discriminate between nodules and other root-derived structures. Protoplasma 149:82-88.

Truchet, G., and Coulomb, P. 1973. Mise en évidence et évolution du système phyto-lysosomal dans les cellules des différentes zones des nodules radiculaires de Pois (Pisum sativum L.). Notion d'hétérophagie. J. Ultrastr. Res. 43:36-57.

Tsien, R. Y. 1998. The green fluorescent protein. Annu. Rev. Biochem. 67:509-544.

Turner, G. L., and Gibson, A. H. 1980. Measurement of nitrogen fixation by indirect means. Pages 111-138 in: Methods for Evaluating Biological Nitrogen Fixation. F. J. Bergersen, ed. Wiley, Chichester, U.K 
Van Brussel, A. A. N., Bakhuizen, R., Van Spronsen, A. C., Spaink, H. P., Tak, T., Lugtenberg, B. J. J., and Kijne, J. 1992. Induction of preinfection thread structures in the leguminous host plant by mitogenic lipooligosaccharides of Rhizobium. Science 257:70-72.

Vance, C. P., and Johnson, L. E. B. 1983. Plant determined ineffective nodules in alfalfa (Medicago sativa): structural and biochemical comparisons. Can. J. Bot. 61:93-106.

Vance, C. P., Johnson, L. E. B., Halvorsen, A. M., Heichel, G. H., and Barnes, D. K. 1980. Histological and ultrastructural observations of
Medicago sativa root nodule senescence after foliage removal. Can. J. Bot. 58:295-309.

Vance, C. P., Johnson, L. E. B., Stade, S., and Groat, R. G. 1982. Birdsfoot trefoil (Lotus corniculatus) root nodules: Morphogenesis and the effect of forage harvest on structure and function. Can. J. Bot. 60:505-518.

Vasse, J., de Billy, F., Camut, S., and Truchet, G. 1990. Correlation between ultrastructural differentiation of bacteroids and nitrogen fixation in alfalfa nodules. J. Bacteriol. 172:4295-4306. 